\title{
Significance of effect of beta blockade on ventilatory function in normal and asthmatic subjects
}

\author{
R.S. JONES \\ Institute of Child Health, University of Liverpool, Alder Hey Children's Hospital, \\ Eaton Road, Liverpool L12 $2 A P$
}

\begin{abstract}
The lability index was examined in 45 normal subjects between 17 and 45 years and also in six patients with asthma, five with a history of asthma in childhood but no clinical attacks, and three with hay fever. The measurements were repeated after $\beta$ blockade with propranolol. Fifteen per cent of the normal subjects exhibited a degree of lability after propranolol which has been previously found only in asthma. It is suggested that a constrictor mechanism exists in normal subjects on exercise but that $\beta$ receptor activity protects them from bronchiolar constriction; post-exercise bronchoconstriction in the asthmatic may be explained in terms of this mechanism. It is also suggested that a proportion of 'normal' subjects are potentially more labile than the remainder of the population and that it is these who may develop clinical asthma if they also happen to be atopic subjects.
\end{abstract}

Bronchodilatation occurs in asthmatic subjects during exercise (Jones, 1962) and bronchoconstriction during or after exercise (Jones, 1962 ; Jones, Wharton, and Buston, 1963). Asthmatics are more labile in these respects than normal subjects. Bronchoconstriction also occurs at rest in response to beta blockade in asthmatic subjects (McNeill, 1964 ; McNeill and Ingram, 1966). It would appear that beta receptor activity plays an important part in maintaining the asthmatic bronchiole in a dilated state. It therefore seemed important to compare the response to beta blockade of normal and asthmatic subjects.

\section{METHODS}

Thirty-seven normal male subjects and eight normal female subjects between the ages of 17 and 45 years were examined. There was no history of asthma or other chest disease. Six patients with asthma, five subjects with a history of asthma in childhood but without attacks in adult life, and three patients with hay fever, all between 16 and 44 years of age, were also examined using similar techniques.

On day 1, at least three readings of the forced expired volume in one second $\left(F E V_{1}\right)$ were made with the subject standing at rest, using a modified Gaensler spirometer. The lability index (LI) was then measured by the technique described by Jones (1966) for children. Exercise for eight minutes was then performed on a treadmill or running along a corridor. The latter is rather more sensitive than the treadmill in that it produces slightly greater bronchoconstriction in some subjects (Blackhall, 1969). The method used was therefore always kept the same in a given subject. The level of exercise chosen was that which would $\stackrel{\odot}{\complement}$ result in steady state exercise at near maximum exercise $\overrightarrow{\vec{B}}$ capacity. Preliminary testing had been carried out on $\frac{0}{3}$ an earlier day in order to assess the exercise level. The duration of exercise was also eight minutes in the asthmatic subjects but the level was usually lower, the procedure being the same as that described for children (Jones et al., 1963). The FEV 1 was measured at one-minute intervals following the termination of $\stackrel{\infty}{x}$ exercise. Exercise was never interrupted for ventilatory measurements during the eight-minute run.

Thirty minutes after the $\mathrm{FEV}_{1}$ had returned to its value prior to exercise, bronchodilatation was pro- $₹$ duced with isoprenaline sulphate $1 \%$ given as an 0 aerosol followed by one minute of brisk exercise as previously described (Jones et al., 1963). Each causes $\frac{7}{O}$ bronchodilatation and the combination is used to achieve maximum bronchodilatation. The FEV $_{1}$ was $N$ again measured at one-minute intervals following the termination of exercise. These data were used to calcu- $\tilde{O}$ late the lability index (Jones, 1966) as follows:

$\mathbf{L I}=\frac{\text { Highest FEV-Lowest FEV }}{\text { FEV at rest }} \times 100$ (normal subjects)
$\mathbf{L I}=\frac{\text { Highest FEV-Lowest FEV }}{\text { Predicted normal FEV }} \times 100$ (asthmatic

On day 2, the $\mathrm{FEV}_{1}$ was measured with the subject ${ }_{0}^{\circ}$ at rest. Propranolol, $100 \mathrm{mg}$, was given by mouth and $\mathbb{\AA}$ 30 minutes later the $\mathrm{FEV}_{1}$ was again measured at rest. $\mathbb{\mathbb { D }}$ The pulse rate was also measured at rest and during $\varrho$ exercise. The 8-minute exercise test was performed $40 \%$ minutes after propranolol had been administered. In 8 
the asthmatic subjects a dose of propranolol which would just fail to cause bronchoconstriction when the subject was at rest was found by trial and error. In three, $100 \mathrm{mg}$ was tolerated, and in the remaining three, 50, 40, and $20 \mathrm{mg}$ respectively.

\section{RESULTS}

NORMAL SUBJECTS (45) Table I shows the increase of $\mathrm{FEV}_{1}$ in response to the bronchodilator drug and brief exercise and the decrease following the bronchoconstrictor effect of eight minutes' exercise. The mean value for the highest minus the lowest $\mathrm{FEV}_{1}$ following these procedures is 0.40 litres, giving a figure for the lability index of $\frac{0 \cdot 40}{4 \cdot 01}$ $\times 100=10 \%$ which is comparable with the normal value for children (Jones, 1966 ; Blackhall, 1969).

In the 20 normal subjects whose $\mathrm{FEV}_{1}$ had been measured at rest before and after propranolol, the $\mathrm{FEV}_{1}$ before was 3.92 litres mean (range 2.44$5 \cdot 14$ litres) and half an hour after propranolol was 3.90 litres mean (range 2.41-5.17 litres). The difference in $\mathrm{FEV}_{1}$ was not significant $(t=0.83, \mathrm{P}>0 \cdot 1)$, so that there is no effect of propranolol on the $\mathrm{FEV}_{1}$ at rest.

In the whole group of 45 subjects the mean $\mathrm{FEV}_{1}$ following propranolol and exercise was significantly lower than the value before exercise (Table II). The $\mathrm{FEV}_{1}$ following bronchodilatation

T A B L E I

45 NORMAL SUBJECTS

\begin{tabular}{|c|c|}
\hline \multicolumn{2}{|l|}{$\begin{array}{l}\text { FEV }_{1} \text { at Rest }\left(\mathrm{FEV}_{1} \mathrm{R}\right) \\
\text { Range } 2 \cdot 62-5 \cdot 23 \text { litres } \\
\text { Mean } 4.01 \\
\text { S.D. } 0.69\end{array}$} \\
\hline \multicolumn{2}{|c|}{$\mathrm{FEV}_{1}$ after Isoprenaline and Exercise for $1 \min \left(\mathrm{FEV}_{1} \mathrm{D}\right)$} \\
\hline $\begin{array}{l}\text { Range } 2 \cdot 57-5 \cdot 80 \text { litres } \\
\text { Mean } 4 \cdot 28 \\
\text { S.D. } 0.77\end{array}$ & $\begin{array}{l}\mathrm{FEV}_{1} \mathrm{R} v \mathrm{FEV}_{1} \mathrm{D} \\
t=7.93 \\
\mathrm{P}<0.001\end{array}$ \\
\hline \multicolumn{2}{|c|}{$\mathrm{FEV}_{1}$ after Exercise for $8 \mathrm{~min}\left(\mathrm{FEV}_{1} \mathrm{C}\right)$} \\
\hline $\begin{array}{l}\text { Range } 2 \cdot 44-5 \cdot 18 \text { litres } \\
\text { Mean } 3 \cdot 88 \\
\text { S.D. } 0 \cdot 68\end{array}$ & $\begin{array}{l}\mathrm{FEV}_{1} \mathrm{R} v \mathrm{FEV}_{1} \mathrm{C} \\
\mathrm{P}=4.81 \\
\mathrm{P}<0.001\end{array}$ \\
\hline
\end{tabular}

T A B L E I I

45 NORMAL SUBJECTS

\footnotetext{
FEV $_{1}$ at Rest after Propranolol (FEV 1 PR)

Range $2 \cdot 41-5 \cdot 17$ litres

Mean 3.93

S.D. 0.68

$\mathrm{FEV}_{1}$ after Propranolol and Exercise $\left(\mathrm{FEV}_{1} \mathrm{PEx}\right)$

Range $2 \cdot 34-4 \cdot 85$ litres

Mean 3.70 litres

S.D. $0 \cdot 65$

FEV $_{1}$ PR $v$ FEV $_{1}$ PEx $\quad t=5.04 ;$ P $<0.001$
}

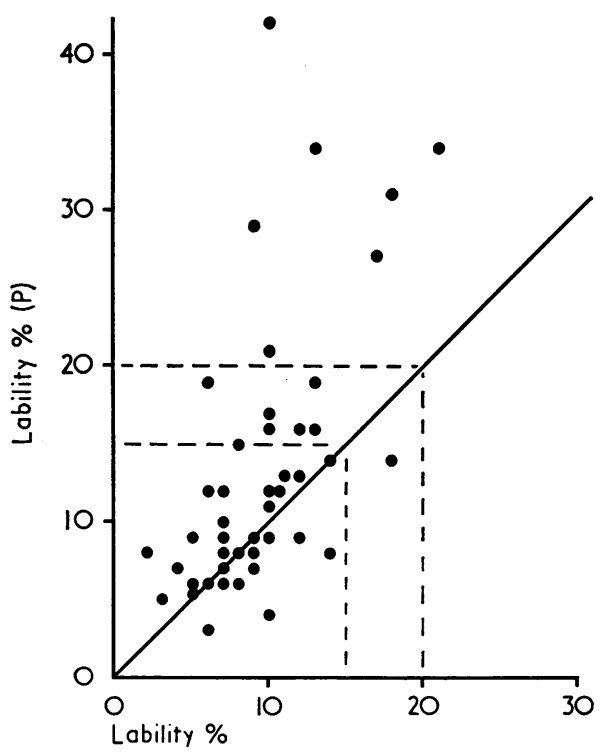

FIG. 1. Change in lability in $\mathbf{4 5}$ normal subjects following $\beta$ blockade. Abscissa: lability. Ordinate: lability following propranolol.

minus the lowest value after beta blockade had a mean of 0.58 litres, which is significantly greater than without blockade $(t=3.69, \mathrm{P}=0.001)$. The mean values for the highest $\mathrm{FEV}_{1}$ (4.28 litres) and the lowest (3.70 litres) following blockade gives a value for the lability index of $14.5 \%$ which compares with $10 \%$ without blockade. This difference is significant $(t=3.63, \mathrm{P}<0.001)$.

This effect of blockade is shown in Figure 1. It can be seen that without blockade all but four of the normal subjects had an LI of less than $15 \%$, which accords with findings in normal children (Jones, 1966). Following blockade 13 (29\%) normal subjects had values above $15 \%$ and seven were greater than $20 \%$, which is outside the normal range. Thus, in seven, the results are entirely comparable with those found in the asthmatic subject. The similarity is also close in that the pattern of constriction is virtually identical with that found in the asthmatic subject, occurring after exercise and having a similar time scale (Fig. 2).

ASTHMATIC SUBJECTS AND THOSE WITH A HISTORY OF ASTHMA IN CHILDHOOD The effect of exercise on ventilatory function has been well described in asthma (Jones, 1962) as has also the action of blockade at rest (McNeill, 1964; McNeill and Ingram, 1966; McNeill, Nairn, Millar, and Ingram, 1966). Since this paper is primarily about the normal subject, only a limited number of 
asthmatics were examined following blockade and exercise. The results are shown in Table III and Figure 3. In three out of the six asthmatics some fall of $F V_{1}$ occurred with the subject at rest despite the attempt by trial and error to find a dose

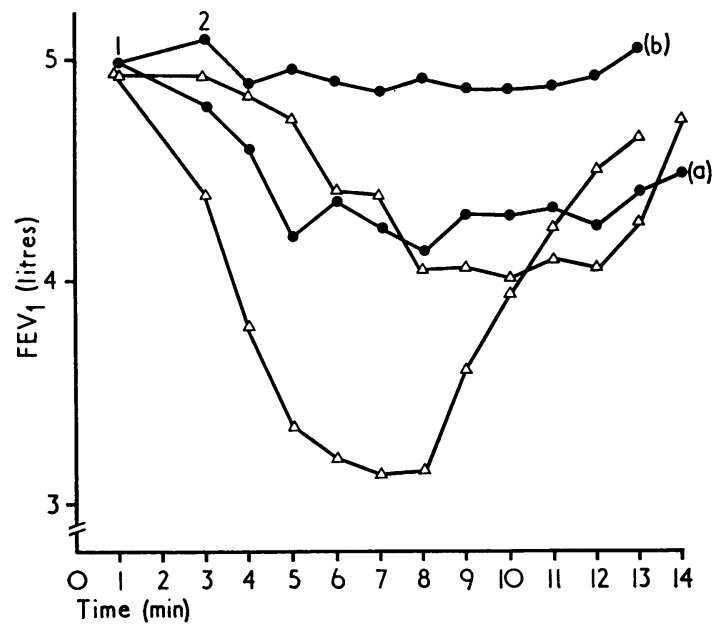

FIG. 2. Effect of propranolol on post-exercise bronchoconstriction. 1. Values before exercise. 2. First values after exercise. Normal subject (LI 18\%) showing change in $F E V_{1}$ following exercise with (a) and without (b) $\beta$ blockade. LI after propranolol $31 \% . \triangle$, Two asthmatic subjects with LI of $24 \%$ and $45 \%$ showing characteristic post-exercise fall in $F E V_{1}$. which was below the threshold. In all instances the $\mathrm{FEV}_{1}$ was allowed to stabilize at its new level and

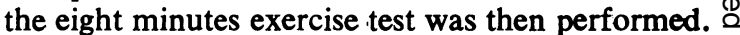
It can be seen that in all but the last subject, in $ळ$ whom the change is probably not significant, $\vec{\circ}$ propranolol potentiated the constrictor effect of exercise.

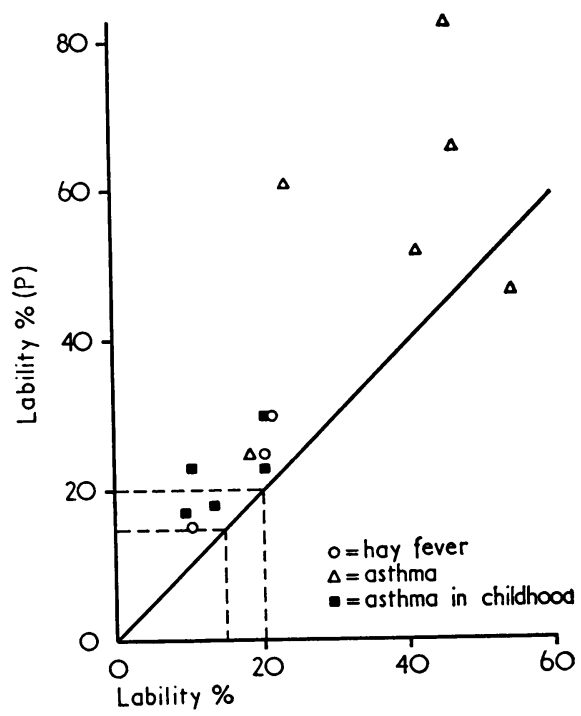

FIG. 3. Changes in lability of patients with asthma and hay fever following $\beta$ blockade.

T A B LE III

6 ASTHMATIC SUBJECTS

\begin{tabular}{|c|c|c|c|c|c|c|}
\hline \multirow{2}{*}{$\begin{array}{c}\text { FEV } 1 \text { at Rest } \\
\text { (litres) }\end{array}$} & \multirow{2}{*}{$\begin{array}{c}\text { FEV }_{1} \text { at Rest } \\
\text { (after propranolol) }\end{array}$} & \multirow{2}{*}{$\begin{array}{c}\text { Dose of } \\
\text { Propranolol } \\
\text { (mg) }\end{array}$} & \multicolumn{2}{|c|}{ Before Blockade } & \multicolumn{2}{|c|}{ After Blockade } \\
\hline & & & $\begin{array}{c}\text { Highest-Lowest } \\
\text { FEV } \\
\text { (litres) }\end{array}$ & $\begin{array}{c}\text { Lability } \\
\text { Index } \\
(\%)\end{array}$ & $\begin{array}{c}\text { Highest-Lowest } \\
\text { FEV } \\
\text { (litres) }\end{array}$ & $\begin{array}{c}\text { Lability } \\
\text { Index } \\
(\%)\end{array}$ \\
\hline $\begin{array}{l}5 \cdot 27 \\
4 \cdot 10 \\
5 \cdot 23 \\
4 \cdot 55 \\
5 \cdot 08 \\
3 \cdot 01\end{array}$ & $\begin{array}{l}5 \cdot 54 \\
4 \cdot 25 \\
4 \cdot 63 \\
5 \cdot 07 \\
4 \cdot 34 \\
2 \cdot 85\end{array}$ & $\begin{array}{r}100 \\
40 \\
20 \\
50 \\
100 \\
30\end{array}$ & $\begin{array}{l}1 \cdot 05 \\
1.88 \\
2 \cdot 54 \\
2 \cdot 55 \\
1 \cdot 22 \\
2 \cdot 17\end{array}$ & $\begin{array}{l}18 \\
41 \\
45 \\
46 \\
23 \\
54\end{array}$ & $\begin{array}{l}1.43 \\
2.38 \\
4.64 \\
3.65 \\
3.50 \\
1.97\end{array}$ & $\begin{array}{l}25 \\
52 \\
83 \\
66 \\
61 \\
49\end{array}$ \\
\hline
\end{tabular}

T A B L E IV

5 SUBJECTS WITH A HISTORY OF ASTHMA IN CHILDHOOD

\begin{tabular}{|c|c|c|c|c|c|}
\hline \multirow{2}{*}{$\begin{array}{l}\mathrm{FEV}_{1} \text { at Rest } \\
\text { (litres) }\end{array}$} & \multirow{2}{*}{$\begin{array}{c}\mathrm{FEV}_{1} \text { at Rest } \\
\text { (after propranolol) }\end{array}$} & \multicolumn{2}{|c|}{ Before Blockade } & \multicolumn{2}{|c|}{ After Blockade } \\
\hline & & $\begin{array}{c}\text { Highest-Lowest FEV } \\
\text { (litres) }\end{array}$ & $\begin{array}{c}\text { Lability Index } \\
(\%)\end{array}$ & $\begin{array}{c}\text { Highest-Lowest FEV } \\
\text { (litres) } \\
\text { (after propranolol) }\end{array}$ & $\underset{(\%)}{\text { Lability Index }}$ \\
\hline $\begin{array}{l}4 \cdot 19 \\
3 \cdot 45 \\
4 \cdot 21 \\
4 \cdot 05 \\
3 \cdot 08\end{array}$ & $\begin{array}{l}3 \cdot 96 \\
3 \cdot 36 \\
4 \cdot 06 \\
4 \cdot 08 \\
3 \cdot 10\end{array}$ & $\begin{array}{l}0.42 \\
0.61 \\
0.27 \\
0.54 \\
0.63\end{array}$ & $\begin{array}{r}10 \\
20 \\
9 \\
13 \\
20\end{array}$ & $\begin{array}{l}0.93 \\
0.74 \\
0.55 \\
0.73 \\
0.92\end{array}$ & $\begin{array}{l}23 \\
23 \\
17 \\
18 \\
30\end{array}$ \\
\hline
\end{tabular}


In two of the five subjects who had grown out of their asthma (Table IV and Fig. 3) the lability was $20 \%$, which is at the upper limit of normal. All were given $100 \mathrm{mg}$ of propranolol and this did not affect the $\mathrm{FEV}_{1}$ at rest, but in all subjects blockade potentiated constriction and in three the lability became frankly abnormal $(23 \%, 23 \%$, and $30 \%)$. Two out of the three subjects with hay fever had relatively high labilities of $20 \%$ and $21 \%$, and in all three there was an increase following blockade (Fig. 3).

\section{DISCUSSION}

It has been shown that the response of the normal adult bronchial tree to isoprenaline and exercise is comparable with the response in the normal child as indicated by the mean figure of $10 \%$ for the lability index. Also, $\beta$ blockade does not change this response at rest but, in a statistically significant number, increase of lability index occurs following blockade and exercise. Fifteen per cent of normal subjects exhibited a degree of lability (LI $>20 \%$ ) which has previously been found only in the asthmatic. This suggests that a proportion of normal subjects are potentially more labile and in this sense are 'at risk' if a constrictor substance is present as a result, for example, of an atopic reaction.

Many mechanisms are known to control the action of bronchiolar muscle and these have been summarized recently by Frick (1969) and Falliers (1971). The role of $\beta$ adrenergic receptors has become apparent since blockade was shown to induce constriction in the asthmatic subject (McNeill, 1964). $\beta$-Receptor activity is thought to depend upon adenyl cyclase since epinephrine enhances the action of this enzyme which catalyses the conversion of adenosine triphosphate (ATP) to cyclic $3^{\prime}, 5^{\prime}$ adenosine monophosphate (cyclic $3^{\prime}, 5^{\prime}$ AMP) (Sutherland and Robison, 1966). Relaxation of bronchiolar muscle follows.

THE NORMAL SUBJECT The bronchiolar muscle cell is subject to control by a series of opposing mechanisms, which if each were operating alone would cause contraction or relaxation of the cell, i.e., constriction or dilatation of the bronchiole. The mechanisms operate through alpha and beta adrenergic receptors, receptors at parasympathetic nerve endings, receptors for substances such as histamine and SRS-A released during the atopic reaction, and possibly other receptors. In the normal subject very little bronchodilatation can be achieved by any procedure, which suggests that the bronchioles are almost fully dilated. Hence the combined action of mechanisms with a dilator effect must exceed the action of those with a constrictor effect. This remains true after beta blockade when the subject is at rest. However, after exercise in addition to beta blockade, constriction occurred in $15 \%$ of normal subjects, which suggests that activation of a receptor site with a contractile effect on the cell is a normal event on exercise and in certain circumstances (e.g., after reduction of $\beta$ adrenergic receptor activity) may result in actual contraction of the cell. However, despite reduction of $\beta$ adrenergic activity, the overall effect on the cell favours relaxation in all but $15 \%$ ( 7 out of 45 subjects). This proportion of normal subjects may be regarded as inherently more labile than the remainder of the population.

THE ASTHMATIC These findings have implications in the asthmatic subject. Mechanisms having constrictor effects are activated by substances which act on receptor sites after release by antigenantibody reactions. These effects are probably counteracted largely by the adrenergic mechanism, for we know that reduction of beta activity in the asthmatic at rest results in bronchoconstriction. Moreover, the results presented here (Tables III and IV) show that on exercise $\beta$ blockade potentiates the lability of the asthmatic. These considerations suggest that, unlike the position in the normal, the adrenergic mechanism is providing a powerful and perhaps greater than normal dilator effect at rest and that adenyl cyclase is therefore not defective in the asthmatic, as suggested by Szentivanyi (1968). When the various mechanisms making for constriction and dilatation are of approximately equal magnitude, then the bronchiole becomes unstable. I take this to be the state of affairs responsible for the abnormally high lability index which is so characteristic and specific in the asthmatic subject.

The findings also offer a possible explanation for post-exercise bronchoconstriction. Given an unstable bronchiole due to an approximate balance between constrictor and dilator mechanisms, then constriction is to be expected during or after exercise due to the enhanced constrictor effect demonstrated here in the normal subject, an effect which is presumably also present in the asthmatic. The fact that constriction does not occur during exercise in the majority of asthmatics may be due to the protective action of catecholamine released on exercise. Various explanations for post-exercise bronchoconstriction have been suggested, including hyperventilation (Fisher, Holton, Buxton, and 
Nadel, 1970; Rebuck and Read, 1968; Ferguson, Addington, and Gaensler, 1969), metabolic acidosis (Seaton, Davies, Gaziano, and Hughes, 1969), and release of a constrictor agent during exercise (Kerr, Govindaraj, and Patel, 1970). However, in view of the evidence presented here, constriction may not be due to some abnormal mechanism occurring on exercise but simply to a normal constrictor mechanism which becomes manifest because it is operating on an unstable bronchiole.

The possibility arises that the measurement of lability index following beta blockade separates off a proportion of normal subjects who have a genetically determined, potentially more labile bronchial tree. The data presented on normal subjects do not exhibit a clearly bimodal distribution on analysis but the numbers examined were too small for any conclusive result and since the technique used is rather cumbersome, it would be difficult to obtain decisive results on a sufficiently large number of normal subjects. It does appear probable, however, that about $15 \%$ of apparently normal subjects have a less inherently stable bronchial tree and may well be 'at risk' if they happen also to be atopic subjects. Asthma may well be a clinical entity which becomes manifest when an individual happens to be atopic and also possesses a more inherently labile bronchial tree.

This work was supported by a grant from the Children's Research Fund.

\section{REFERENCES}

Blackhell, M. I. (1969). The effect of age on ventilatory function in asthma. M.D. thesis, University of Liverpool.
Falliers, C. J. (1971). Neurohumoral and enzymatic activity in asthma. Proc. int. congr. Pediatrics, Vienna. Vol. IX, p. 243.

Ferguson, A., Addington, W. W., and Gaensler, E. A. (1969). Dyspnoea and bronchospasm from inappropriate postexercise hyperventilation. Ann. intern. Med., 71, 1063.

Fisher, H. K., Holton, P., Buxton, R. St. J., and Nadel, J. A. (1970). Resistance to breathing during exercise-induced asthma attacks. Amer. Rev. resp. Dis., 101, 885.

Frick, O. L. (1969). Mediators of atopic and anaphylactic reactions. Pediat. Clin. N. Amer., 16, No. 1, 95.

Jones, R. S. (1962). The effect of exercise on ventilatory function in the child with asthma. Brit. J. Dis. Chest, 56, 78.

Wharton, M. J., and Buston, M. H. (1963). The place of physical exercise and bronchodilator drugs in the assessment of the asthmatic child. Arch. Dis. Childh., 38, 539.

- (1966). Assessment of respiratory function in the asthmatic child. Brit. med. J., 2, 972.

Kerr, J. W., Govindaraj, M., and Patel, K. R. (1970). Effect of alpha-receptor blocking drugs and disodium cromoglycate on histamine hypersensitivity in bronchial asthma. Brit. med. J., 2, 139.

McNeill, R. S. (1964). Effect of a $\beta$-adrenergic-blocking agent, propranolol, on asthmatics. Lancet, 2, 1101.

- and Ingram, C. G. (1966). Effect of propranolol on ventilatory function. Amer. J. Cardiol., 18, 473.

— Nairn, J. R., Millar, J. S., and Ingram, C. G. (1966). Exercise-induced asthma. Quart. J. Med., 35, 55.

Rebuck, A. S., and Read, J. (1968). Exercise-induced asthma. Lancet, 2, 429.

Seaton, A., Davies, G., Gaziano, D., and Hughes, R. O (1969). Exercise-induced asthma. Brit. med. J., 3, 556.

Sutherland, E. W., and Robison, G. A. (1966). The role of cyclic-3', 5'-AMP in responses to catecholamines and other hormones. Pharmacol. Rev., 18, 145.

Szentivanyi, A. (1968). The $\beta$-adrenergic theory of the atopic abnormality in bronchial asthma. J. Allergy, 42, 203. 